
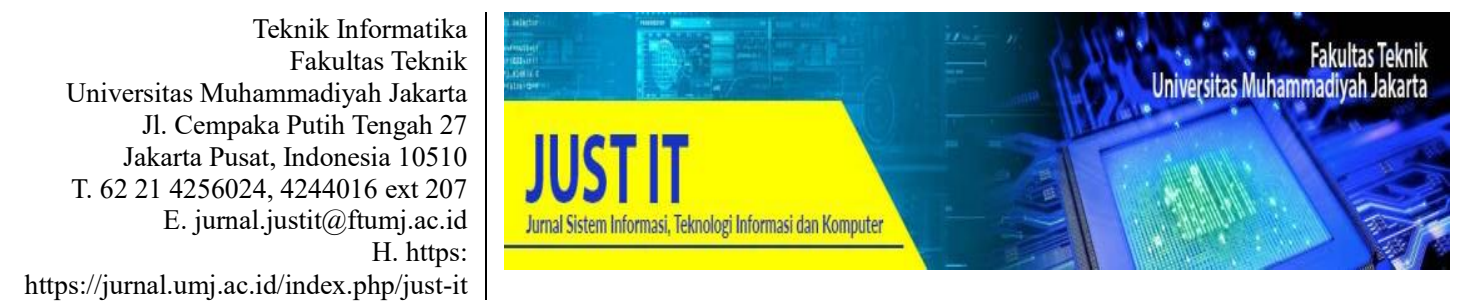

\title{
Sistem Human Capital Management Menggunakan Metode Scrum
}

\author{
Beni Septian ${ }^{1}$, Indra Komara Jayadi², Munawar Holil ${ }^{3 \text {, dan Inge Handriani }}{ }^{4}$ \\ 1.2.3.4Program Studi Sistem Informasi, Fakultas Ilmu Komputer, Universitas Mercu Buana \\ beni.septian@gmail.com¹,indrakomara13@gmail.com², holilmunawar026@gmail.com³, \\ inge.handriani@mercubuana.ac.id ${ }^{4}$
}

\begin{abstract}
Abstrak
Human Resources Information System (HRIS) adalah suatu perangkat lunak yang berfungsi untuk menjalankan tugas sehari-hari dari bagian Human Resources mulai dari pengelolaan data karyawan, absensi, dan sebagainya. Sistem Human Capital Management bertujuan untuk meningkatkan kinerja dan meminimalisir kesalahan pada proses bisnis yang ada pada bagian sumber daya manusia sehingga memudahkan kegiatan operasional bagian sumber daya manusia khususnya pada proses rekrutmen, manajemen data karyawan, absensi dan penghitungan gaji. Dalam pengembangannya sistem ini menggunakan PIECES dalam membantu menganilisa permasalahan - permasalahan yang ada dan menggunakan metode scrum yang meliputi storyboard berdasarkan fitur apasaja yang akan di kembangkan, product backlog, sprints, daily scrum dan sprint review. Dengan adanya sistem human capital management dapat meningkatkan jumlah pelamar pekerja dan mempercepat proses screening kandidat dengan adanya profile matching. Pada proses pencatatan data karyawan dan absensi informasi yang didapat lebih akurat dan efeketif serta pada proses penghitungan gaji karyawan lebih cepat dan mengurangi kesalahan karena sudah terintegrasi dengan absensi karyawan.
\end{abstract}

Kata Kunci: Human Capital Management, HRIS, SCRUM, PIECES, sumber daya manusia

\begin{abstract}
Human Resource Information System (HRIS) is a device used for daily tasks from the Human Resources department starting from employee data management, attendance, etc. The Human Resource Management System supports improvement and minimizes problems in existing business processes in human resources specifically in the recruitment process, employee data management, attendance and loan lending calculations. In its development, this system uses PIECES to help analyze existing problems and use the Scrum method that contains storyboards based on whatever features will be developed, product savings, sprints, daily scrums, and sprint reviews. With the existence of a human resource management system can increase the number of worker applicants and improve the screening process of candidates by matching profiles. In the process of recording employee data and the attendance of information obtained is more accurate and effective and in the process of calculating employee salaries faster and reduce problems related to employee absenteeism.
\end{abstract}

Keywords: Human Capital Management, HRIS, SRUM, PIECES, Human Resource 


\section{PENDAHULUAN}

Pada era globalisasi ini informasi sangatlah penting bagi semua kalangan khususnya sebuah perusahaan. Informasi dari suatu bagian memiliki keterkaitan satu sama lain, sehingga sangat penting adanya integrasi informasi antara bagian. Menurut Devi Lestari (Lestari, 2014) Informasi yang cepat tepat dan terintegrasi akan memperlancar proses pada bagian yang terkait yang ada dalam suatu perusahaan.

Human Resources adalah orang-orang yang bertugas untuk mengelola tenaga kerja yang ada pada suatu perusahaan, mulai dari proses perekrutan calon tenaga kerja hingga pengelolaan para tenaga kerja yang sudah ada di perusahaan. Menurut Jogiyanto HM HRIS merupakan sistem informasi untuk mendukung kegiatan-kegiatan manajer di fungsi sumber daya manusia. Fungsi ini dulunya bernama fungsi department personalia sekarang diubah namanya menjadi fungsi SDM untuk menunjukan bahwa manusia di dalam organisasi adalah sumber daya ekonomis yang penting (Jogiyanto, 2005).

Di zaman seperti sekarang setiap perusahaan pada umumnya menggunakan sebuah sistem informasi kepegawaian untuk mempercepat proses dan memudahkan staff HRD dalam melakukan pengelolaan data karyawan, seperti data pribadi karyawan, data absensi karyawan, data izin/cuti karyawan, penggajian karyawan hingga rekrutmen.

Setiap perusahaan pada saat tertentu membutuhkan tenaga kerja berkualitas (Handriani, Sidik, Noor, Multazam, \& Wijaya, 2019) dan menurut Dody, dkk Rekrutmen juga dapat dikatakan sebagai proses untuk mendapatkan sejumlah SDM yang berkualitas untuk menduduki suatu jabatan atau pekerjaan dalam suatu perusahaan (Meiastoko, Kertahardi, \& Susilo, 2013). Karena itu rekrutmen menjadi salah satu proses penting yang dilakukan pada bagian HRD, proses rekrutmen sendiri meliputi membuka lowongan pekerjaan, metode perekrutan hingga kandidat diterima. Semua proses terebut termasuk bagian dalam human resource information system. Berdarsakan peneilitian yang dilakukan oleh Indra dan
Suhendra (Ranggadara \& Suhendra, 2018) menggunakan e-recruitment berpotensi untuk menghemat waktu karena dapat menilai calon banyak calon karyawan melalui jaringan internet dan tidak menggunakan kertas.

Pengolahan data karyawan menjadi hal penting lainnya dari proses yang ada pada bagian HRD, pengolahan data karyawan pada HRIS difokuskan pada pencatatan administrasi karyawan seperti data karyawan, tunjangan, pajak, posisi pada perusahaan dsb. Masih banyak perusahaan yang melakukan pencatatan karyawan menggunakan aplikasi pengolah kata dan pengolah angka seperti pada penilitian yang dilakukan oleh Dedi, dkk (Dedi, Fuad, \& Setiawan, 2014)[6] sehingga didalam menghasilkan seluruh laporan yang akurat dan tepat relatif lama, tidak fleksibel serta kurang lengkapnya laporan yang dihasilkan.

Manajemen absensi dan cuti karyawan sangat diperlukan oleh HRD sebagai data perusahaan dan juga bahan evaluasi. menurut Albertus (Setyabudhi, 2017). Kegiatan administrasi absensi maupun cuti kerja akan berpengaruh pada keadaan data perorangan karyawan maupun keseluruhan serta semua proses yang ada dalam sebuah perusahaan. Untuk itu diperlukan pencatatan data yang efektif dan efisien serta mudah diakses oleh karyawan ataupun manajemen.

Sistem penghitungan gaji karyawan saat ini sangat diperlukan untuk mempermudah dan meminimalisir kesalahan dalam proses penghitungan gaji karyawan, pernyataan ini selaras dengan pernyataan Fio, dkk yaitu Sistem penggajian juga dapat mengurani adanya penipuan atau kesalahan yang terjadi sengaja atau tidak sengaja yang dapat mengakibatkan kerugian bagi perusahaan. Sistem penggajian dapat berfungsi sebagai kontrol dalam kegiatan perusahaan (Alfiandi, Kertahadi, \& Nuzula, 2014). Untuk ini diperlukan sistem penghitungan gaji karywan yang terintegrasi dengan absensi.

Jika manajemen SDM yang dilakukan oleh HRD tidak bersajalan dengan baik seperti pada penilitian yang dilakukan oleh Julian dan Fani (Wibawa \& Julianto, 2016) perusahaan akan mengalami kemunduran dan hal terburukanya berhentinya proses bisnis pada 
perusahaan. Untuk itu hal yang dibutuhkan perusahaan saat ini adalah saling terintegrasinya informasi pada proses tersebut sehingga mempercepat proses bisnis dimulai dari proses perekrutan, manajemen data karyawan, absensi karyawan hingga penggajian karyawan untuk mengurangi kesalahan yang terjadi akibat kelalaian pekerja dan juga meningkatkan efisiensi kerja perusahaan khususnya pada bagian manajemen sumber daya manusia.

PT. Perdana Perkasa Elastindo (Persaels) adalah sebuah perusahaan yang bergerak dibidang ourtsourcing. Perusahaan memiliki karyawan yang tersebar di banyak perusahaan. pada perusahaan ini bagian HRD melakukan pencatatan data karyawan menggunakan aplikasi pengolah kata angka seperti microsoft excel. Data karyawan saat ini sudah banyak sehingga adanya kendala yang dialami jika harus mencari data karyawan ataupun menambahkan data karyawan yaitu lambat dalam membuka file data karyawan.

Absensi karyawan dilakukan dengan mencatat kehadiran selama satu bulan di kertas kemudian disertakan tanda tangan dari manajer masing divisi. Setiap karyawan mengirimkan dokumen absensi yang sudah ditandatangani oleh manajer mereka kepada HRD melalui email ataupun menyerahkan dokumennya secara langsung. Sering kali staff HRD sulit melakukan verifikasi kebenaran absensi yang dikirimkan oleh karyawan. Dalam melakukan penghitungan gaji karyawan memerlukan waktu yang cukup lama karena staff HRD melakukan verifikasi absensi dahulu lalu melakukan penghitungan gaji karyawan berdasarkan absensi karyawan dan juga potongan yang ada, staff HRD melakukan penghitungan gaji dengan aplikasi pengolah kata dengan format yang sudah ada.

Permasalahan yang ada pada proses rekrutmen mirip dengan penilitian yang dilakukan oleh Wulan dan Ilham (Ayu \& Perdana, 2014) yaitu perusahaan belum memiliki portal sendiri sehingga membka lowongan pekerjaan melalui pihak ketiga ataupun melalui broadcast pada grup chat. Dalam prosesnya staff HRD melakukan screening awal memerlukan waktu yang cukup lama, Staff HRD juga melakukan koordinasi dengan user terkait penilaian kandidat setelah melakukan interview namun komunikasi yang ada belum baik dan memakan waktu yang cukup lama yang mengakibatkan proses rekrutmen lebih lama.

Berdasarkan permasalahan tersebut, maka penelitian ini membahas Aplikasi Human Capital Management. Sistem informasi ini dimaksudkan untuk mendukung dan mempermudah aktivitas pada bagian HRD pada proses perekrutan, manajemen data, absensi, cuti dan penggajian yang saling terintegrasi.

Tujuan pengembangan aplikasi Human Capital Management Meningkatkan efisiensi waktu dalam proses penyaringan administrasi pada proses rekrutmen dengan berbasis web yaitu pengembang dari penilitian yang dilakukan oleh Farid, dkk (Habibie, 2012), meminimalisir kesalahan pada pencatatan cuti dan absensi karyawan, memudahkan HRD dalam melakukan verifikasi data absensi, Mempercepat proses rekapitulasi absensi karyawan untuk mendukung proses perhitungan gaji karyawan serta meminimalisir kesalahan dalam penghitungan gaji karyawan.

\section{METODOLOGI PENELITIAN}

Penelitian ini menggunakan metode pengembang sistem yang mengacu pada metode agile. Metode Agile menggunakan model spiral, yang merupakan serangkaian iterasi, atau revisi, berdasarkan masukan dari pengguna (Shelly \& Rosenblatt, 2012). Tahapan dalam setiap iterasi dalam model spiral meliputi:

1. Perencanaan (planning)

Pada tahap ini, menjelaskan tentang tujuan pengembangan sistem yang akan dibuat.

\section{Analisis (analysis)}

Pada tahap ini, dilakukan analisis pada sistem yang berjalan saat ini pada proses yang ada pada bagian sumber daya manusia menggunakan workflow dan PIECES untuk menentukan sistem yang akan dikembangan layak atau tidak.

3. Teknik (engineering)

Pada tahap ini, dilakukan pengembangan prototipe yang mencakup seluruh kebutuhan sistem informasi human capital management. 4.Evaluasi (evaluation) 
Pada tahap ini, dilakukan penilaian dan pengujian untuk mengembangkan tujuan dari sistem informasi human capital management untuk proses iterasi selanjutnya.

Dalam pengembangannya, ketika ada pada tahap Teknik dan evaluasi menggunakan metode SCRUM sama seperti penilitian yang dilakukan oleh aris, dkk (Rahman, Setiawan, \& Handriani, 2019) dan juga Usman (Ependi, 2018). Namun ada perbedaan pada modul yang dikembangkan

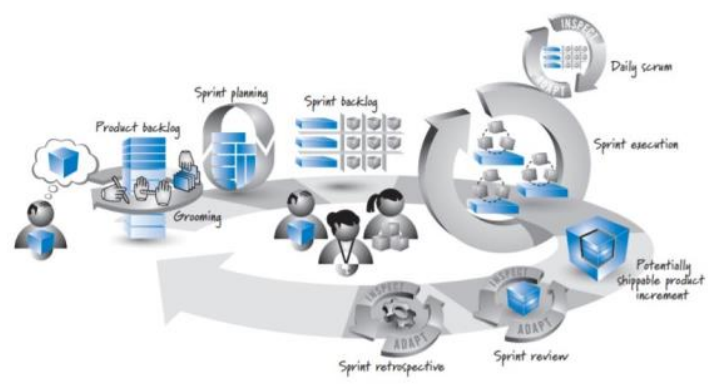

Gambar 1. SCRUM framework

Menurut Kenneth S. Rubin (Rubin, 2012) Siklus sprint Scrum berulang, dimulai lagi dengan tim pengembangan menentukan set item backlog produk terpenting berikutnya yang dapat dilakukan lengkap. Setelah sejumlah sprint telah selesai, produk visi pemilik akan terwujud dan solusinya dapat dirilis. Dan Berikut detailnya :

Product Backlog

Product Backlog adalah fitur diperlukan untuk memenuhi visi pemilik produk (owner). Untuk pengembangan produk yang sedang berlangsung, product backlog meliputi fitur baru, perubahan pada fitur yang ada, cacat yang membutuhkan perbaikan, peningkatan teknis, dan sebagainya.

Sprints

Sprint adalah kotak waktu sehingga mereka selalu memiliki tanggal mulai dan berakhir yang tetap, dan umumnya mereka semua memiliki durasi yang sama. Sprint baru menyusul setelah sprint yang sebelumnya selesai.

\section{Daily Scrum}

Setiap hari, idealnya pada saat yang sama, anggota tim pengembangan menyisihkan waktu (15 menit atau kurang). Aktivitas inspeksi dan adaptasi ini kadang-kadang disebut sebagai stand-up harian karena semua orang berdiri selama pertemuan untuk membantu mempromosikan kinerjanya.

\section{Sprint Review}

Tujuan dari sprint review adalah untuk memeriksa dan mengadaptasi produk yang sedang dibangun. Yang penting untuk kegiatan ini adalah percakapan yang terjadi di antara para pesertanya, yang meliputi tim Scrum, pemangku kepentingan, sponsor, dan pelanggan. Percakapan difokuskan pada meninjau fitur yang baru saja selesai dalam konteks upaya pengembangan secara keseluruhan.

\section{HASIL DAN PEMBAHASAN}

Perencanaan

Tujuan dari penelitian Aplikasi Human Capital Management adalah Meningkatkan efisiensi waktu dalam proses penyaringan administrasi pada proses rekrutmen. Meminimalisir kesalahan pada pencatatan cuti dan absensi karyawan serta memudahkan HRD dalam melakukan verifikasi data absensi karyawan. Meminimalisir kesalahan data dalam penghitungan gaji karyawan serta mempercepat proses rekapitulasi absensi karyawan untuk mendukung proses perhitungan gaji karyawan.

Analisis

Analisis sistem berjalan akan dijelaskan dengan workflow dari masing masing proses bisnis yang ada, sebagai berikut :

1) Rekrutmen 


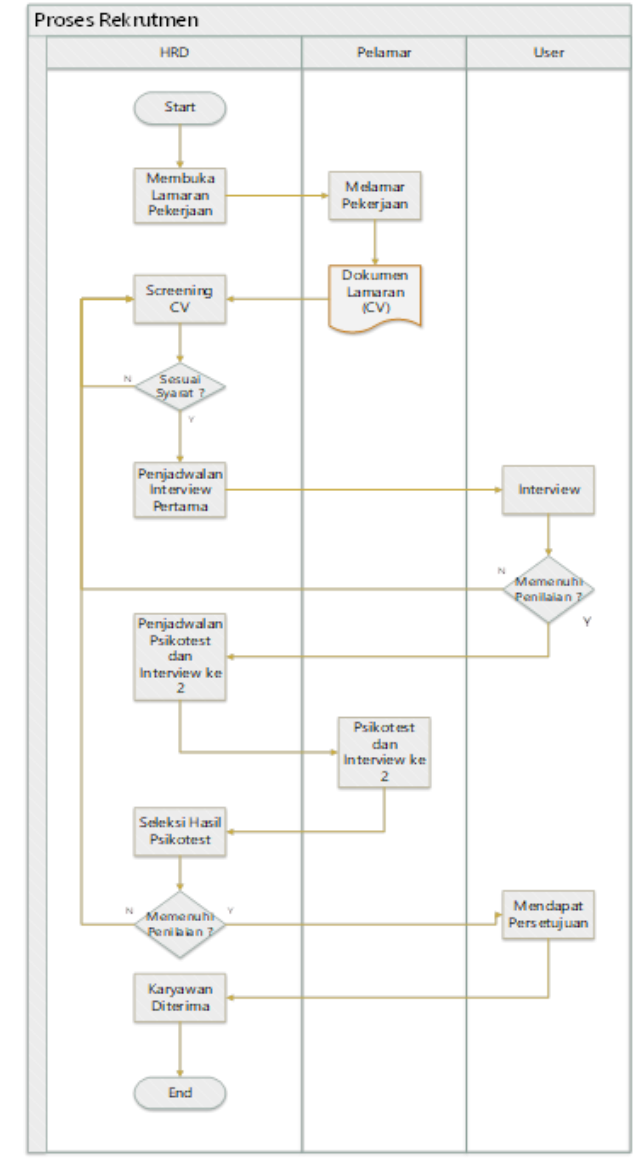

Gambar 2. Workflow rekrutmen sistem berjalan

Prosedur penggajian karyawan yang saat ini berjalan pada PT. Perdana Perkasa Elastindo sebagai berikut :

1. HRD membuka lamaran pekerjaan di JobsDB ataupun broadcast melalui WA.

2. Pelamar apply lamaran dan mengirimkan CV mereka melalui Jobsdb atau email ke bagian rekrutmen.

3. HRD melakukan screening berdasarkan CV yang diterima.

4. Jika sesuai dengan permintaan user maka HRD melakukan penjadwalan interview dengan user.

5. User melakukan interview dengan pelamar dan memberikan penilaian sesuai dengan format dari perusahaan.

6. Jika penilaikan sesuai HRD akan melakukan penjadwalan untuk psikotest dan interview ke 2 dengan HRD.
7. HRD melakukan penilaian berdasarkan psioktest dan interview.

8. Jika cocok akan diteruskan ke user untuk mendapatkan persetujuan.

9. Setelah mendapat persetujuan dari user HRD menghubungi pelamar dan melakukan pendataan karyawan.

2) Manajemen data karyawan

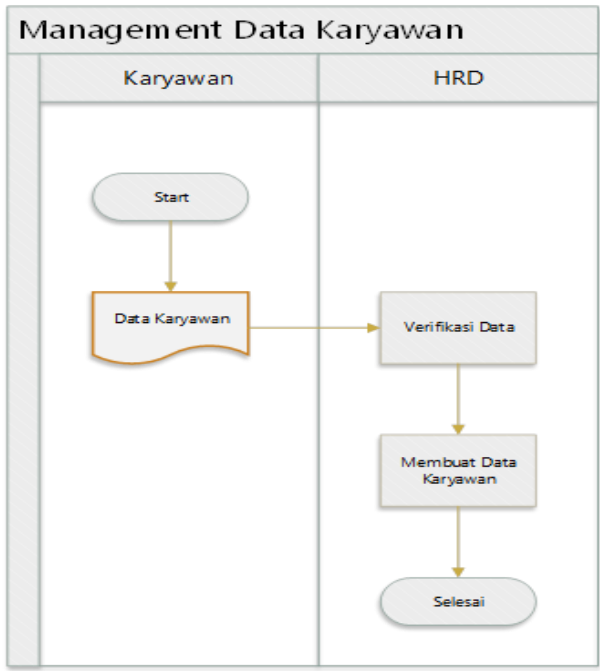

Gambar 3. Workflow manajemen data karyawan sistem berjalan

Prosedur Manajemen Data Karyawan yang saat ini berjalan pada PT. Perdana Perkasa Elastindo sebagai berikut :

1. Karyawan Menyiapkan data data pribadi untuk diberikan kepada HRD. Data tersebut adalah KTP, KK, NPWP, Nomor Rekening Bank, BPJS Kesahatan, BPJS Ketanakerjaan dan ijazah.

2. Karyawan Memberikan Data Pribadi kepada HRD dalam bentuk softcopy dan hardcopy.

3. HRD memastikan data yang diberikan sudah lengkap.

4. HRD melakukan pencatatan data karyawan menggunakan Excel.

5. HRD menyimpan data karyawan dengan format excel.

3) Absensi karyawan 


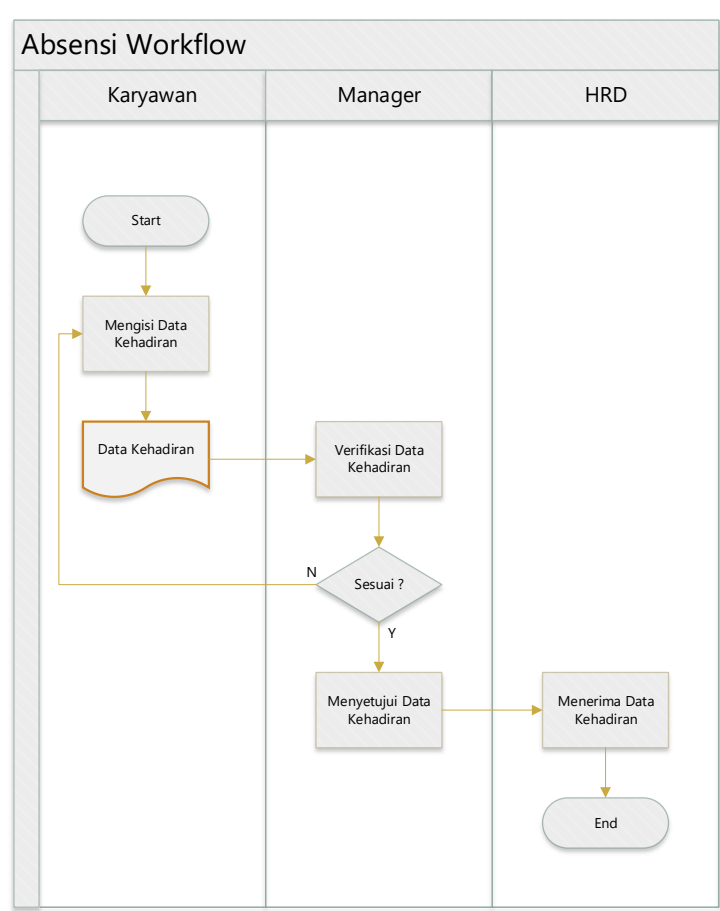

Gambar 4. Workflow Absensi karyawan sistem berjalan

Prosedur absensi karyawan yang saat ini berjalan pada PT. Perdana Perkasa Elastindo sebagai berikut :

1. Karyawan mengisi formulir absensi selama satu bulan dengan keterangan jam kerja dan pekerjaan yang dilakukan

2. Karyawan memberikan formulir absensi kepada manajer atau supervisor untuk ditanda tangan.

3. Manajer melakukan verifikasi data kehadiran karyawan selama satu bulan.

4. Jika sesuai Manajer dan SPV akan menandatangani formulir absensi.

5. Jika tidak sesuai karyawan akan melakukan revisi sesuai dengan permintaan Manajer.

6. Dokumen absensi akan dikirimkan ke HRD melalui email.

7. HRD akan menyimpan dokumen absensi karyawan.

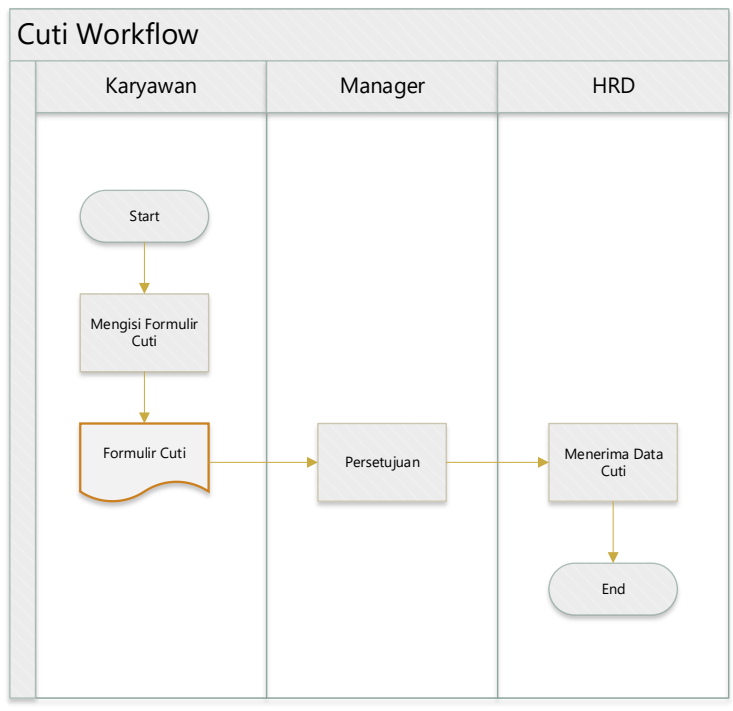

Gambar 5. Workflow pengajuan cuti sistem berjalan

Prosedur cuti karyawan yang saat ini berjalan pada PT. Perdana Perkasa Elastindo sebagai berikut:

1. Karyawan mengisi formulir cuti dengan format yang disediakan.

2. Karyawan meberikan formulir cuti kepada manajer untuk ditandatangani.

3. Manajer melakukan persetujuan dengan menandatangani formulir cuti.

4. Formulir cuti dikirimkan ke HRD melalui email.

4) Penghitungan gaji karyawan

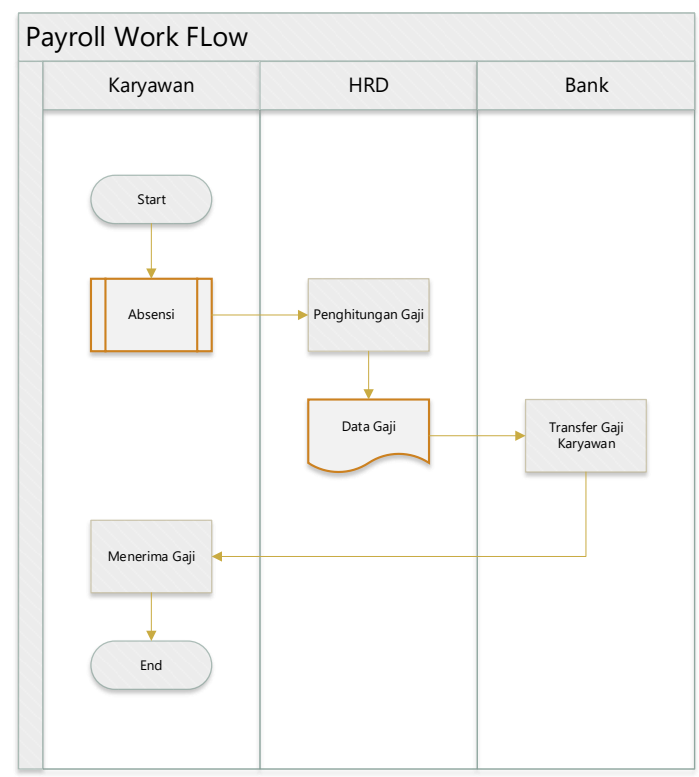

Gambar 6. Workflow Absensi karyawan sistemberjalan 
Prosedur penggajian karyawan yang saat ini berjalan pada PT. Perdana Perkasa Elastindo sebagai berikut :

1. Karyawan memberikan data kehadiran selama satu bulan ke HRD melalui email.

2. HRD melakukan penghitungan gaji karyawan sesuai dengan data kehadiran dan ketentuan grading.

3. Setalah data gaji terkumpul HRD akan mengirimkan data gaji ke bank.

4. Bank akan mentransfer gaji karyawan sesuai dengan data dari HRD.

5. Karyawan menerima gaji.

Berdasarakan proses bisnis yang saat ini berjalan pada perusahaan dalam proses rekrutmen, manajemen data karyawan, absensi dan pengajian karyawan ditemukan beberapa permasalahan. Dari permasalahan yang ada dilakukan Analisa menggunakan metode PIECES sebagai berikut :

a) Performance (Kinerja)

Tabel berikut adalah hasil analisa kinerja pada sistem yang berjalan.

TABEL 1

TABEL ANALISA KINERJA

\begin{tabular}{|l|l|l|}
\hline Indikator & Kendala & Solusi \\
\hline Response & $\bullet$ Dalam proses & $\bullet$ Dibuatkan \\
Time dari & rekrutmen & Form data \\
Proses & memerlukan & lamaran \\
yang & waktu yang & $\bullet$ Dibuatkan \\
dijalani & lama untuk & profile \\
dan & koordinasi & matching. \\
banyaknya & dengan user & • Dibuatkan \\
hasil & dan untuk & form absensi \\
pekerjaan. & proses & berbasis web. \\
& screening & $\bullet$ Dibuatkan \\
& awal. & form \\
& $\bullet$ Verifikasi & penghitungan \\
& absensi & gaji \\
& karyawan & terintegrasi \\
& lambat. & dengan \\
& Penghitungan & absensi \\
& Gaji & karyawan. \\
& karyawan & \\
& memerlukan & \\
& waktu yang & \\
& lama. & \\
& &
\end{tabular}

b) Information (informasi)

Tabel berikut adalah hasil analisa informasi pada sistem yang berjalan.

TABEL 2

TABEL ANALISA INFORMASI

\begin{tabular}{|c|c|c|}
\hline Indikator & Kendala & Solusi \\
\hline $\begin{array}{l}\text { Fleksibilitas } \\
\text { dan } \\
\text { kemudahan } \\
\text { dalam } \\
\text { memasukkan } \\
\text { data dan } \\
\text { melihat } \\
\text { keluaran } \\
\text { data }\end{array}$ & $\begin{array}{l}\text { - Memasukkan } \\
\text { data } \\
\text { karyawan } \\
\text { lambat karena } \\
\text { saat ini } \\
\text { menggunaka } \\
\text { n excel dan } \\
\text { juga data } \\
\text { sudah cukup } \\
\text { banyak. } \\
\text { - Sulit melihat } \\
\text { data absensi } \\
\text { karyawan. } \\
\text { Karyawan } \\
\text { harus } \\
\text { menghubungi } \\
\text { staff HRD } \\
\text { jika ingin } \\
\text { melihat data } \\
\text { pribadi } \\
\text { sendiri dan } \\
\text { slip gaji. } \\
\text { Tidak } \\
\text { terintegrasi } \\
\text { data } \\
\text { rekrutmen } \\
\text { dengan data } \\
\text { karyawan. }\end{array}$ & $\begin{array}{l}\text { - Dibuatkan } \\
\text { Form data } \\
\text { karyawan } \\
\text { yang } \\
\text { terintegras } \\
\text { i dengan } \\
\text { sistem } \\
\text { rekrutmen. } \\
\text { - Dibuatkan } \\
\text { halaman } \\
\text { melihat } \\
\text { absensi } \\
\text { karyawan } \\
\text { dan bisa di } \\
\text { export ke } \\
\text { pdf dan } \\
\text { csv. } \\
\text { Dibuatkan } \\
\text { user untuk } \\
\text { setiap } \\
\text { karyawan } \\
\text { dengan } \\
\text { hak untuk } \\
\text { melihat } \\
\text { data } \\
\text { pribadi } \\
\text { dan slip } \\
\text { gaji. }\end{array}$ \\
\hline
\end{tabular}

c) Economic (ekonomi)

Tabel berikut adalah hasil analisa ekonomi pada sistem yang berjalan.

TABEL 3

TABEL ANALISA EKONOMI

\begin{tabular}{|c|c|c|}
\hline Indikator & Kendala & Solusi \\
\hline $\begin{array}{l}\text { Prosedur } \\
\text { yang } \\
\text { berjalan saat } \\
\text { ini dinilai } \\
\text { dari biaya } \\
\text { penyelengga } \\
\text { raannya. }\end{array}$ & $\begin{array}{l}\text { Membuat } \\
\text { lowongan } \\
\text { pekerjaan } \\
\text { melalui jobsdb } \\
\text { (pihak ketiga) } \\
\text { tidak } \\
\text { mempunyai } \\
\text { portal lowongan } \\
\text { sendiri. }\end{array}$ & $\begin{array}{l}\text { Dibuatkan } \\
\text { portal } \\
\text { rekrutmen } \\
\text { yang bisa } \\
\text { memposting } \\
\text { lowongan } \\
\text { pekerjaan }\end{array}$ \\
\hline
\end{tabular}

d) Control (kontrol)

Tabel berikut adalah hasil analisa kontrol pada sistem yang berjalan.

TABEL 4 


TABEL ANALISA KONTROL
\begin{tabular}{|l|l|l|}
\hline \multicolumn{1}{|c|}{ Indikator } & \multicolumn{1}{|c|}{ Kendala } & \multicolumn{1}{|c|}{ Solusi } \\
\hline Kemampuan & Sulit melakukan & Dibuatkan \\
prosedur saat & verifikasi & absensi \\
ini menilai & kebenaran & berbasis web \\
/mendeteksi & absensi & dan realtime. \\
adanya & karyawan. & \\
kecurangan/ & & \\
kesalahan. & & \\
\hline
\end{tabular}

e) Efficiency (Efisiensi)

Tabel berikut adalah hasil analisa efisiensi pada sistem yang berjalan.

TABEL 5

\begin{tabular}{|c|c|c|}
\hline \multicolumn{3}{|c|}{ TABEL ANALISA EFISIENSI } \\
\hline Indikator & Kendala & Solusi \\
\hline $\begin{array}{l}\text { Efisiensi } \\
\text { prosedur } \\
\text { yang saat } \\
\text { ini } \\
\text { berjalan, } \\
\text { fleksibilitas } \\
\text { dan usaha } \\
\text { yang } \\
\text { dilakukan } \\
\text { pada sistem } \\
\text { yang saat } \\
\text { ini } \\
\text { berjalan. }\end{array}$ & $\begin{array}{l}\text { - Saat ini } \\
\text { belum } \\
\text { memiliki } \\
\text { sistem } \\
\text { informasi } \\
\text { pada bagian } \\
\text { HRD } \\
\text { sehingga } \\
\text { kurang } \\
\text { efisien dalam } \\
\text { proses } \\
\text { pencatatan } \\
\text { data } \\
\text { karyawan. } \\
\text { - Karyawan } \\
\text { harus selalu } \\
\text { bertanya ke } \\
\text { staff HRD } \\
\text { untuk } \\
\text { informasi } \\
\text { yang } \\
\text { berkaitan } \\
\text { dengan Cuti, } \\
\text { data } \\
\text { karyawan dan } \\
\text { slip gaji. }\end{array}$ & \begin{tabular}{|l} 
- \\
Dibuatkan \\
korm data \\
yaryawan \\
terintegrasi \\
dengan \\
sistem \\
rekrutmen. \\
- Dibuatkan \\
user untuk \\
setiap \\
karyawan \\
dengan hak \\
untuk \\
melihat \\
data pribadi \\
dan slip \\
gaji.
\end{tabular} \\
\hline
\end{tabular}

f) Service (Pelayanan)

Tabel berikut adalah hasil analisa kinerja pada sistem yang berjalan.

TABEL 6

TABEL ANALISA

\begin{tabular}{|l|l|l|}
\hline \multicolumn{4}{|c|}{ Indikator } & \multicolumn{2}{|c|}{ Kendala } & \multicolumn{1}{|c|}{ Solusi } \\
\hline Sistem yang & Tidak ada & Dibuatkan \\
saat ini & Sistem & sistem \\
berjalan & Informasi & informasi \\
menghasilkan & sehingga data & manajemen \\
informasi & masih di & data \\
\hline
\end{tabular}

\begin{tabular}{|c|c|c|}
\hline $\begin{array}{l}\text { yang akurat, } \\
\text { konsisten, } \\
\text { fleksibel, } \\
\text { mudah } \\
\text { dipahami dan } \\
\text { mudah } \\
\text { dipelajari. }\end{array}$ & $\begin{array}{l}\text { simpan pada } \\
\text { Komputer di } \\
\text { HRD dan } \\
\text { proses yang } \\
\text { ada tidak } \\
\text { saling } \\
\text { terintegrasi. } \\
\text { Sehingga } \\
\text { banyak } \\
\text { proses yang } \\
\text { terhambat } \\
\text { dikarenakan } \\
\text { informasi } \\
\text { yang dimiliki } \\
\text { setiap } \\
\text { stakeholder } \\
\text { berbeda. }\end{array}$ & $\begin{array}{l}\text { karyawan } \\
\text { yang } \\
\text { terintegrasi } \\
\text { dengan } \\
\text { sistem } \\
\text { rekrutmen. }\end{array}$ \\
\hline
\end{tabular}

3.3 Teknik dan evaluasi menggunakan SCRUM

Pada tahap ini menggunakan metode SCRUM dimulai dari storyboard, product backlog, sprint, daily scrum hingga sprint review yang mencangkup seluruh kebutuhan sistem informasi human capital management.

\section{Story Board}

Dari hasil analisa sistem berjalan dibuat storyboard berdasarkan fitur - fitur apa saja yang akan dikembangkan dari informasi yang didapat dari pemangku kepentingan. Berikut perancangan storyboard : 


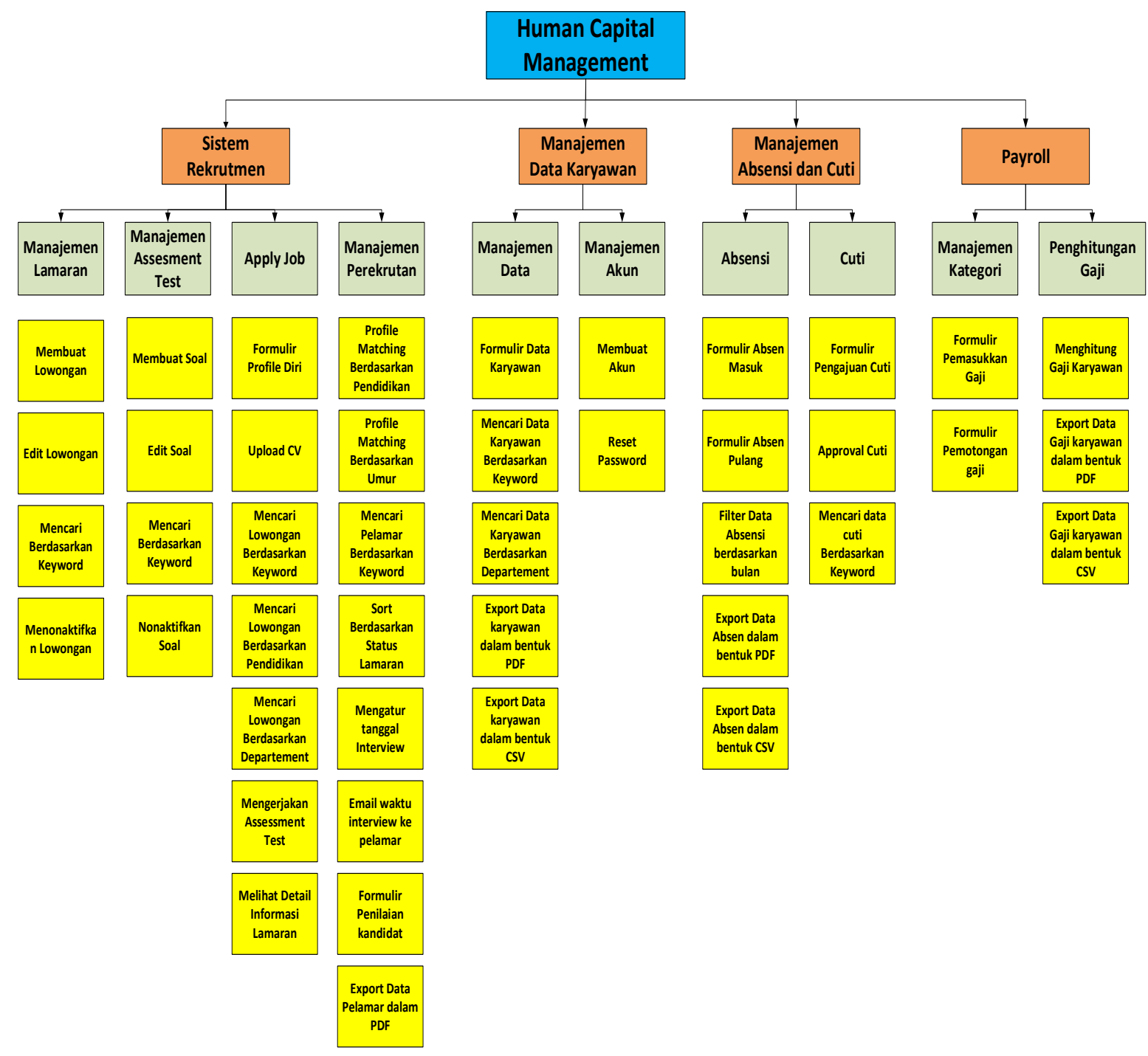

Gambar 7. Storyboard

2. Product Backlog

Selanjutnya adalah membuat product backlog yaitu menentukan fitur - fitur yang akan ada dan diurutkan berdasarkan prioritas. Berikut ini adalaha product backlog pada aplikasi human capital management :

TABEL 7

TABEL PRODUCT BACKLOG

\begin{tabular}{|l|l|l|}
\hline No & Deskripsi Fitur & Prioritas \\
\hline 1 & Mengelola assessment test & Very high \\
\hline 2 & Mengelola lamaran pekerjaan & Very high \\
\hline 3 & Fitur login pelamar & Very high \\
\hline
\end{tabular}

\begin{tabular}{|l|l|l|}
\hline 4 & Melamar Pekerjaan & Very high \\
\hline 5 & Mengelola proses perekrutan & High \\
\hline 6 & Mengelola data Karyawan & High \\
\hline 7 & Mengelola akun & High \\
\hline 8 & Fitur login karyawan & Medium \\
\hline 9 & Sistem absensi & Medium \\
\hline 10 & Sistem cuti & Medium \\
\hline 11 & Penghitungan gaji & Low \\
\hline
\end{tabular}

\section{Sprints}

Setelah menentukan product backlog langkah selanjutnya adalah menentukan sprint 
berdasarkan prioritas pada product backlog. Berikut ini adalah sprints pada aplikasi human capital management.

1) Sprint 1 ( Mengelola Asssessment Test)

TABEL 8

TABEL SPRINT 1

\begin{tabular}{|c|c|c|}
\hline $\begin{array}{l}\text { Fitur } \\
\text { Backlog }\end{array}$ & Task & $\begin{array}{l}\text { Estimasi } \\
\text { (Hari) }\end{array}$ \\
\hline \multirow{8}{*}{$\begin{array}{c}\text { Mengelola } \\
\text { assessment } \\
\text { test } \\
\text { rekrutmen }\end{array}$} & Desain Database & 2 \\
\hline & $\begin{array}{l}\text { Desain } \\
\text { Antarmuka }\end{array}$ & 2 \\
\hline & $\begin{array}{l}\text { Development } \\
\text { page membuat } \\
\text { soal }\end{array}$ & 3 \\
\hline & $\begin{array}{l}\text { Development } \\
\text { page edit soal }\end{array}$ & 3 \\
\hline & $\begin{array}{l}\text { Development } \\
\text { fitur mencari } \\
\text { berdasarkan } \\
\text { Keyword }\end{array}$ & 2 \\
\hline & $\begin{array}{l}\text { Development } \\
\text { page Detail Soal }\end{array}$ & 2 \\
\hline & Testing & 2 \\
\hline & Total & 16 \\
\hline
\end{tabular}

Sprint 1 berfokus pada mengelola assessment test rekrutmen yang terdiri dari 7 task dengan estimasi pengerjaan 16 hari.

2) Sprint 2 ( Mengelola Lamaran Pekerjaan) TABEL 9

TABEL SPRINT 2

\begin{tabular}{|l|l|l|}
\hline $\begin{array}{l}\text { Fitur } \\
\text { Backlog }\end{array}$ & Task & $\begin{array}{l}\text { Estimasi } \\
\text { (Hari) }\end{array}$ \\
\hline $\begin{array}{c}\text { Mengelola } \\
\text { Lamaran } \\
\text { Pekerjaan }\end{array}$ & Desain Database & 2 \\
\cline { 2 - 3 } & Desain Antarmuka & 2 \\
\cline { 2 - 3 } & $\begin{array}{l}\text { Development page } \\
\text { membuat lowongan } \\
\text { pekerjaan }\end{array}$ & 3 \\
\cline { 2 - 3 } & $\begin{array}{l}\text { Development page } \\
\text { edit lowongan } \\
\text { pekerjaan }\end{array}$ & 3 \\
\cline { 2 - 3 } & $\begin{array}{l}\text { Development fitur } \\
\text { mencari berdasarkan } \\
\text { Keyword }\end{array}$ & 2 \\
\cline { 2 - 3 } & $\begin{array}{l}\text { Development page } \\
\text { nonaktifkan } \\
\text { lowongan pekerjaan }\end{array}$ & 2 \\
\cline { 2 - 3 } & Testing & 2 \\
\hline & Total & 16 \\
\hline
\end{tabular}

Sprint 2 berfokus pada mengelola lamaran pekerjaan yang terdiri dari 7 task dengan estimasi pengerjaan 16 hari.

3) Sprint 3 ( Login Pelamar)

TABEL 10

TABEL SPRINT 3

\begin{tabular}{|c|l|l|}
\hline $\begin{array}{l}\text { Fitur } \\
\text { Backlog }\end{array}$ & Task & $\begin{array}{l}\text { Estimasi } \\
\text { (Hari) }\end{array}$ \\
\hline $\begin{array}{l}\text { Login } \\
\text { Pelamar }\end{array}$ & Desain Database & 1 \\
\cline { 2 - 3 } & Desain Antarmuka & 1 \\
\cline { 2 - 3 } & $\begin{array}{l}\text { Development page } \\
\text { register }\end{array}$ & 2 \\
\cline { 2 - 3 } & $\begin{array}{l}\text { Development page } \\
\text { login page }\end{array}$ & 2 \\
\cline { 2 - 3 } & $\begin{array}{l}\text { Development } \\
\text { forgot password }\end{array}$ & 2 \\
\cline { 2 - 3 } & Testing & 1 \\
\hline & Total & 9 \\
\hline
\end{tabular}

Sprint 3 berfokus pada fitur login pelamar yang terdiri dari 6 task dengan estimasi pengerjaan 9 hari.

4) Sprint 4 ( Melamar Pekerjaan )

TABEL 11

TABEL SPRINT 4

\begin{tabular}{|c|l|l|}
\hline $\begin{array}{c}\text { Fitur } \\
\text { Backlog }\end{array}$ & Task & $\begin{array}{l}\text { Estimasi } \\
\text { (Hari) }\end{array}$ \\
\hline $\begin{array}{c}\text { Melamar } \\
\text { Pekerjaan }\end{array}$ & Desain Database & 2 \\
\cline { 2 - 3 } & Desain Antarmuka & 2 \\
\cline { 2 - 3 } & $\begin{array}{l}\text { Development form } \\
\text { profile pelamar }\end{array}$ & 3 \\
\cline { 2 - 3 } & $\begin{array}{l}\text { Development upload } \\
\text { CV }\end{array}$ & 2 \\
\cline { 2 - 3 } & $\begin{array}{l}\text { Development fitur } \\
\text { mencari berdasarkan } \\
\text { Keyword }\end{array}$ & 2 \\
\cline { 2 - 3 } & $\begin{array}{l}\text { Development fitur } \\
\text { mencari berdasarkan } \\
\text { kategori pendidikan }\end{array}$ & 2 \\
\cline { 2 - 3 } $\begin{array}{l}\text { Development fitur } \\
\text { mencari berdasarkan } \\
\text { kategori departemen }\end{array}$ & 2 \\
\cline { 2 - 3 } $\begin{array}{l}\text { Development page } \\
\text { mengerjakan } \\
\text { assessment test }\end{array}$ & 4 \\
\cline { 2 - 3 } $\begin{array}{l}\text { Development page } \\
\text { detail informasi } \\
\text { lowongan }\end{array}$ & 2 \\
\cline { 2 - 3 } Testing & 3 \\
\hline & Total & 24 \\
\hline
\end{tabular}


Sprint 4 berfokus pada fitur melamar pekerjaan yang terdiri dari 10 task dengan estimasi pengerjaan 24 hari.

5) Sprint 5 ( Mengelola Perektutan ) TABEL 12

TABEL SPRINT 5

\begin{tabular}{|l|l|l|}
\hline \multirow{3}{*}{$\begin{array}{l}\text { Fitur } \\
\text { Backlog }\end{array}$} & Task & $\begin{array}{l}\text { Estimas } \\
\text { i (Hari) }\end{array}$ \\
\hline \multirow{4}{*}{$\begin{array}{l}\text { Mengelola } \\
\text { perekrutan }\end{array}$} & Desain Database & 2 \\
\cline { 2 - 3 } & Desain Antarmuka & 2 \\
\cline { 2 - 3 } & $\begin{array}{l}\text { Development } \\
\text { profile matching }\end{array}$ & 6 \\
\cline { 2 - 3 } & $\begin{array}{l}\text { Development page } \\
\text { detail pelamar }\end{array}$ & 2 \\
\cline { 2 - 3 } & $\begin{array}{l}\text { Development fitur } \\
\text { mencari pelamar } \\
\text { berdasarkan } \\
\text { Keyword }\end{array}$ & 2 \\
\cline { 2 - 3 } & $\begin{array}{l}\text { Development fitur } \\
\text { schedule interview }\end{array}$ & 4 \\
\cline { 2 - 3 } & $\begin{array}{l}\text { Development form } \\
\text { penilaian pelamar }\end{array}$ & 3 \\
\cline { 2 - 3 } & Testing & 3 \\
\hline & Total & 24 \\
\hline
\end{tabular}

Sprint 5 berfokus pada mengelola perekrutan yang terdiri dari 8 task dengan estimasi pengerjaan 24 hari.

6) Sprint 6 ( Manajemen Data Karyawan ) TABEL 13

TABEL SPRINT 6

\begin{tabular}{|c|c|c|}
\hline $\begin{array}{l}\text { Fitur } \\
\text { Backlog }\end{array}$ & Task & $\begin{array}{l}\text { Estimas } \\
\text { i (Hari) }\end{array}$ \\
\hline \multirow{7}{*}{$\begin{array}{l}\text { Manajemen } \\
\text { Data } \\
\text { Karyawan }\end{array}$} & Desain Database & 2 \\
\hline & Desain Antarmuka & 2 \\
\hline & $\begin{array}{l}\text { Development form } \\
\text { data karyawan }\end{array}$ & 3 \\
\hline & $\begin{array}{lr}\text { Development } & \text { page } \\
\text { detail } & \text { data } \\
\text { karyawan } & \\
\end{array}$ & 3 \\
\hline & $\begin{array}{l}\text { Development fitur } \\
\text { mencari pelamar } \\
\text { berdasarkan } \\
\text { Keyword }\end{array}$ & 2 \\
\hline & $\begin{array}{l}\text { Development fitur } \\
\text { mencari pelamar } \\
\text { berdasarkan } \\
\text { Departemen }\end{array}$ & 2 \\
\hline & Testing & 2 \\
\hline
\end{tabular}

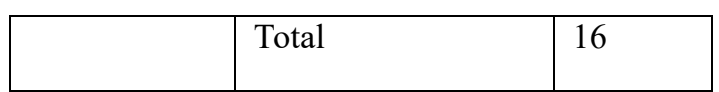

Sprint 6 berfokus pada manajemen data karyaawan yang terdiri dari 7 task dengan estimasi pengerjaan 16 hari.

7) Sprint 7 ( Mengeola Akun )

TABEL 14

TABEL SPRINT 7

\begin{tabular}{|c|l|l|}
\hline $\begin{array}{c}\text { Fitur } \\
\text { Backlog }\end{array}$ & Task & $\begin{array}{l}\text { Estimas } \\
\text { i (Hari) }\end{array}$ \\
\hline $\begin{array}{c}\text { Mengelo } \\
\text { la Akun }\end{array}$ & Desain Database & 1 \\
\cline { 2 - 3 } & Desain Antarmuka & 1 \\
\cline { 2 - 3 } & $\begin{array}{l}\text { Development fitur } \\
\text { membuat akun } \\
\text { berdasarkan } \\
\text { karyawan }\end{array}$ & 3 \\
\cline { 2 - 3 } & $\begin{array}{l}\text { Development fitur } \\
\text { Ubah password }\end{array}$ & 2 \\
\cline { 2 - 3 } & Testing & 1 \\
\hline & Total & 8 \\
\hline
\end{tabular}

Sprint 7 berfokus pada fitur mengelola akun yang terdiri dari 5 task dengan estimasi pengerjaan 8 hari.

8) Sprint 8 ( Login Karyawan )

TABEL 15

TABEL SPRINT 8

\begin{tabular}{|c|l|l|}
\hline $\begin{array}{c}\text { Fitur } \\
\text { Backlog }\end{array}$ & Task & $\begin{array}{l}\text { Estimasi } \\
\text { (Hari) }\end{array}$ \\
\hline \begin{tabular}{c} 
Login $\begin{array}{c}\text { Karyawa } \\
\mathrm{n}\end{array}$ \\
\cline { 2 - 3 }
\end{tabular} & Desain Database & 1 \\
\cline { 2 - 3 } & Desain Antarmuka & 1 \\
\cline { 2 - 3 } & $\begin{array}{l}\text { Development Page } \\
\text { Login Karyawan }\end{array}$ & 3 \\
\cline { 2 - 3 } & $\begin{array}{l}\text { Development Page } \\
\text { lupa password }\end{array}$ & 2 \\
\cline { 2 - 3 } & Testing & 1 \\
\hline & Total & 8 \\
\hline
\end{tabular}

Sprint 8 berfokus pada fitur login karyawan yang terdiri dari 5 task dengan estimasi pengerjaan 8 hari.

9) Sprint 9 ( Sistem Absensi ) 


\begin{tabular}{|c|c|c|}
\hline \multicolumn{3}{|c|}{$\begin{array}{c}\text { TABEL } 16 \\
\text { TABEL SPRINT } 9\end{array}$} \\
\hline $\begin{array}{l}\text { Fitur } \\
\text { Backlo } \\
\text { g }\end{array}$ & Task & $\begin{array}{l}\text { Estimasi } \\
\text { (Hari) }\end{array}$ \\
\hline \multirow{10}{*}{$\begin{array}{l}\text { Sistem } \\
\text { Absensi }\end{array}$} & Desain Database & 2 \\
\hline & Desain Antarmuka & 2 \\
\hline & $\begin{array}{ll}\text { Development } & \text { form } \\
\text { absen masuk } & \end{array}$ & 2 \\
\hline & $\begin{array}{ll}\text { Development } & \text { form } \\
\text { absen pulang } & \\
\end{array}$ & 2 \\
\hline & $\begin{array}{l}\text { Development page detail } \\
\text { absensi }\end{array}$ & 2 \\
\hline & $\begin{array}{ll}\text { Development } & \text { filter } \\
\text { berdasarkan bulan } & \end{array}$ & 2 \\
\hline & $\begin{array}{ll}\begin{array}{l}\text { Development } \\
\text { export PDF }\end{array} & \text { fitur } \\
\end{array}$ & 2 \\
\hline & $\begin{array}{l}\text { Development fitur } \\
\text { export csv }\end{array}$ & 2 \\
\hline & Testing & 2 \\
\hline & Total & 18 \\
\hline
\end{tabular}

Sprint 8 berfokus pada fitur login karyawan yang terdiri dari 9 task dengan estimasi pengerjaan 18 hari.

10) Sprint 10 ( Sistem Cuti )

TABEL 17

TABEL SPRINT 10

\begin{tabular}{|c|l|l|}
\multicolumn{3}{|c}{ TABEL SPRINT 10 } \\
\hline $\begin{array}{l}\text { Fitur } \\
\text { Backlog }\end{array}$ & Task & $\begin{array}{l}\text { Estimasi } \\
\text { (Hari) }\end{array}$ \\
\hline \multirow{4}{*}{$\begin{array}{c}\text { Sistem } \\
\text { Cuti }\end{array}$} & Desain Database & 2 \\
\cline { 2 - 3 } & Desain Antarmuka & 2 \\
\cline { 2 - 3 } & $\begin{array}{l}\text { Development page input } \\
\text { sisa cuti }\end{array}$ & 2 \\
\cline { 2 - 3 } & $\begin{array}{l}\text { Development form } \\
\text { pengajuan cuti approval }\end{array}$ & 2 \\
\cline { 2 - 3 } & $\begin{array}{l}\text { Development apt } \\
\text { cuti }\end{array}$ & 2 \\
\cline { 2 - 3 } & $\begin{array}{l}\text { Development page data } \\
\text { pengajuan cuti }\end{array}$ & 2 \\
\cline { 2 - 3 } & Testing & 14 \\
\hline & Total & \\
\hline
\end{tabular}

Sprint 10 berfokus pada fitur login karyawan yang terdiri dari 7 task dengan estimasi pengerjaan 14 hari.

\begin{tabular}{|c|c|c|}
\hline \multicolumn{3}{|c|}{$\begin{array}{c}\text { TABEL } 18 \\
\text { TABEL SPRINT } 11\end{array}$} \\
\hline $\begin{array}{r}\text { Fitur } \\
\text { Backlog }\end{array}$ & Task & $\begin{array}{l}\text { Estimasi } \\
\text { (Hari) }\end{array}$ \\
\hline \multirow{8}{*}{$\begin{array}{l}\text { Penghitung } \\
\text { an Gaji }\end{array}$} & Desain Database & 2 \\
\hline & Desain Antarmuka & 2 \\
\hline & $\begin{array}{l}\text { Development } \\
\text { data absensi }\end{array}$ & 4 \\
\hline & $\begin{array}{l}\text { Development form } \\
\text { penghitungan gaji }\end{array}$ & 4 \\
\hline & $\begin{array}{l}\text { Development page } \\
\text { list gaji }\end{array}$ & 2 \\
\hline & $\begin{array}{l}\text { Development export } \\
\text { slip gaji }\end{array}$ & 2 \\
\hline & Testing & 2 \\
\hline & Total & 18 \\
\hline
\end{tabular}

Sprint 10 berfokus pada fitur login karyawan yang terdiri dari 7 task dengan estimasi pengerjaan 18 hari.

\subsection{Daily Scrum}

Selama sprint berlangsung akan dilakukan daily scrum yang dilakukan setiap hari selama 15 menit, dilakukan mulai pukul 08.00 08.15. daily scrum dilakukan oleh scrum master dengan anggotanya sebagai evaluasi harian pekerjaan apa saja yang sudah dilakukan, pekerjaan yang akan dilakukan dan kendala apa yang terjadi selama proses berlangsung. Daily scrum membantu scrum master memastikan bahwa sprint berjalan sesuai dengan planning.

\subsection{Sprint Review}

Langkah selanjutnya adalah sprint review yang diikuti oleh scrum master, pemangku kepentingan dan pengguna. Sprint review dimaksudkan memberikan informasi fitur yang baru saja selesai dikerjakan dari sistem secara keseluruhan dan langsung dapat dievaluasi oleh pemangku kepentiangan ataupun pengguna. Berikut ini adalah hasil tampilan dari aplikasi Human Capital Management :

\section{1) Sprint 11 ( Penghitungan Gaji )}




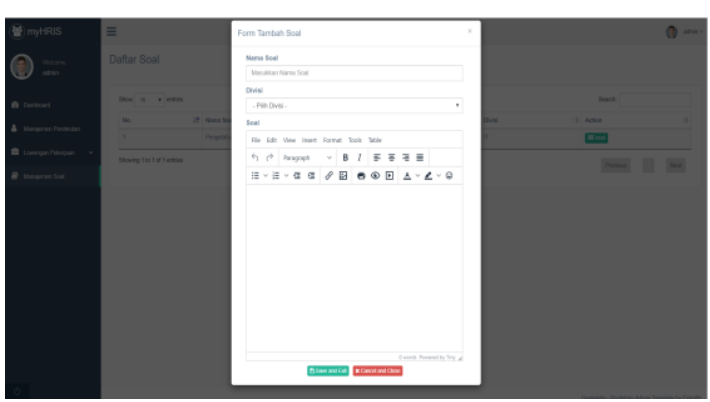

Gambar 8. Halaman Mengelola Soal Assessment Test Pada halaman ini dapat dilakukan penambahan dan daftar soal assessment test yang akan di integrasikan dengan lowongan pekerjaan.

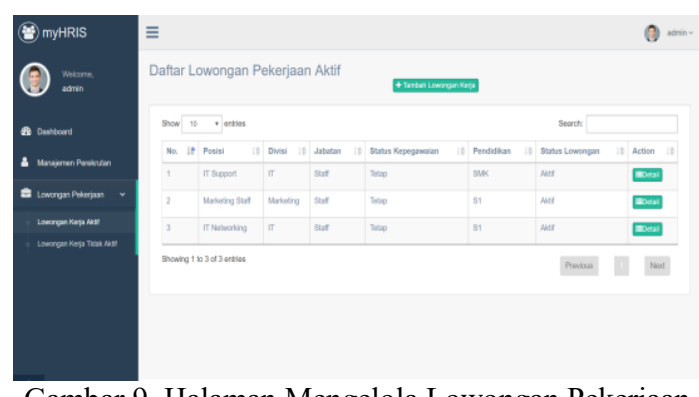

Gambar 9. Halaman Mengelola Lowongan Pekerjaan Pada menu lowongan pekerjaan membuat lowongan pekerjaan dan daftar lowongan pekerjaan yang aktif, lowongan pekerjaan yang aktif bisa dilihat oleh pelamar dan lowongan yang tidak aktif tidak akan bisa dilihat oleh pelamar.

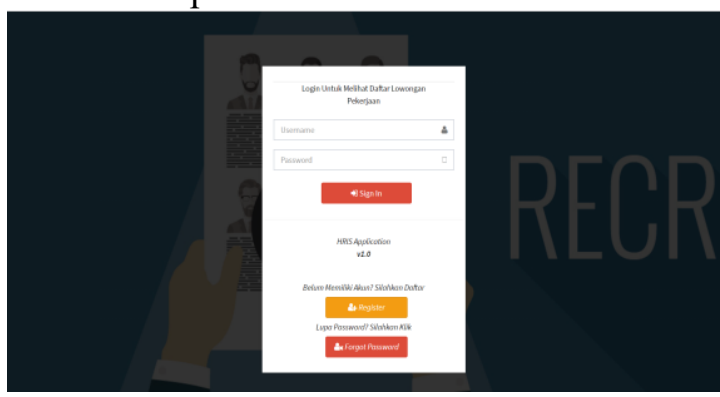

Gambar 10. Halaman Login Pelamar

Pada halaman ini difungsikan untuk pelamar, pelamar dapat melakukan registrasi, login dan lupa password pada halaman ini.

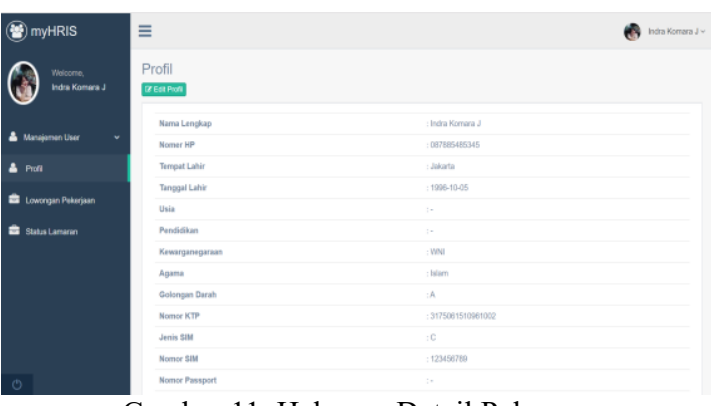

Gambar 11. Halaman Detail Pelamar

Pada halaman ini pelamar harus mengisi formulir data diri dan upload cv untuk kebutuhan melamar pekerjaan.
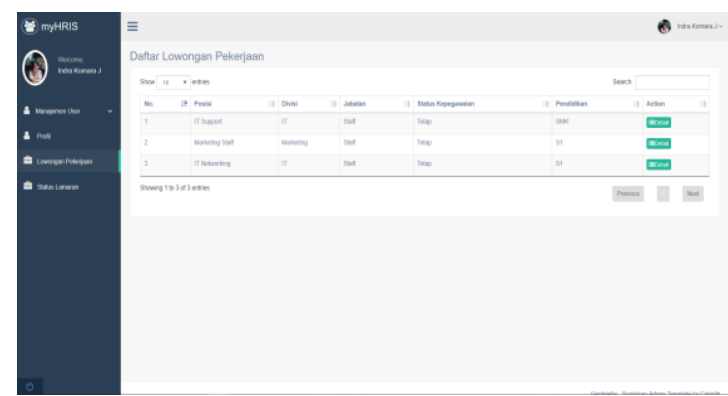

Gambar 12. Halaman Daftar Lowongan Pekerjaan Pada menu lowongan pekerjaan pelamar dapat melihat lowongan pekerjaan apa saja yang terjedia dan melakukan proses lamaran. Proses lamaran terdiri dari melakukan lamaran pada lowongan pekerjaan dan melakukan assessment test.

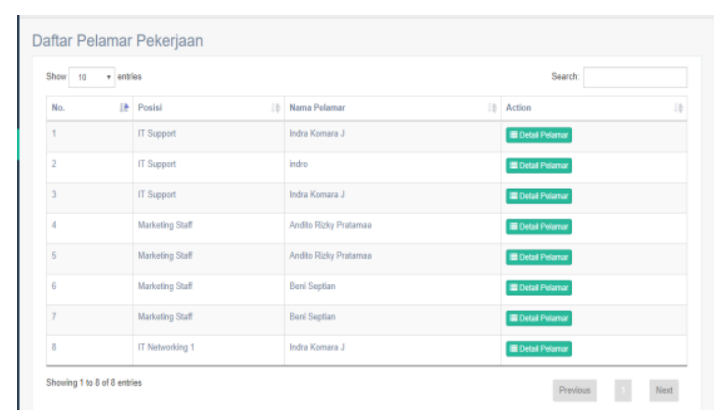

Gambar 13. Halaman Daftar Pelamar

Pada menu daftar pelamar perusahaan dapat melihat daftar pelamar berdasarkan lowongan pekerjaan yang sudah dibuat. 


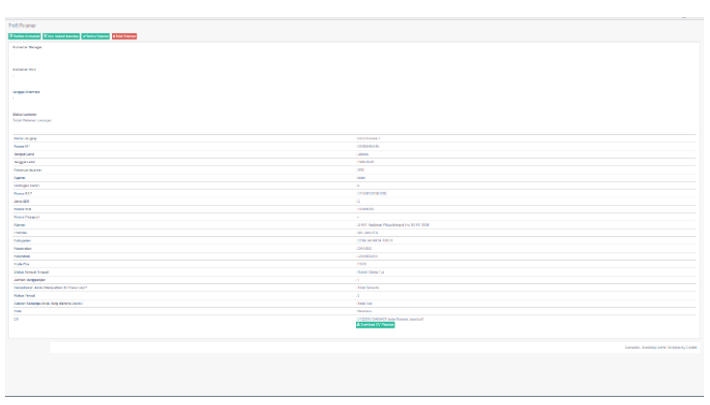

Gambar 14. Halaman Detail Pelamar

Pada menu ini perusahaan dapat melihat detail pelamar dan bisa membuat jadwal interview dengan pelamar. Pada halaman ini juga terdapat formulir penilaian pelamar yang dapat diisi oleh hrd dan user yang melakukan interview.

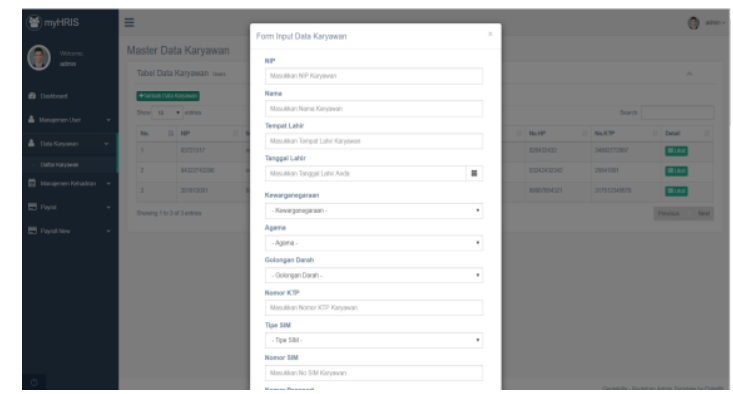

Gambar 15. Halaman Master Data Karyawan Pada menu ini dapat memasukkan data karyawan dan melihat data karyawan.

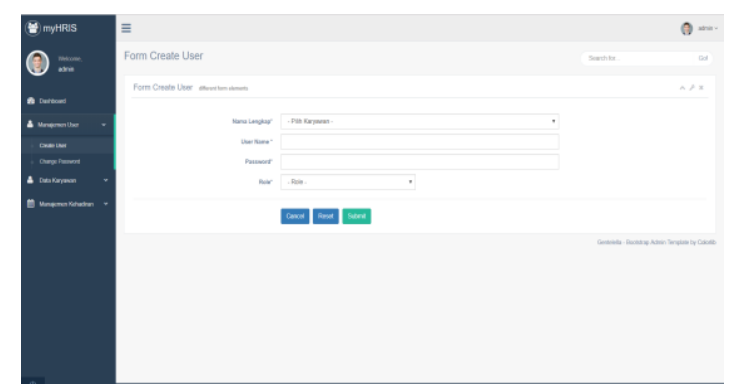

Gambar 16. Halaman Membuat User

Pada menu difungsikan untuk membuat user untuk karyawan masuk kedalam sistem sesuai dengan role masing - masing.
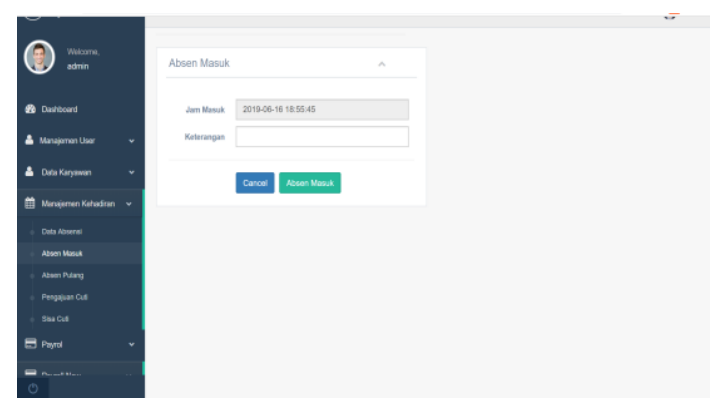

Gambar 17. Halaman Absensi Karyawan Pada menu karyawan melakukan absen masuk dan absen pulang melalui web.
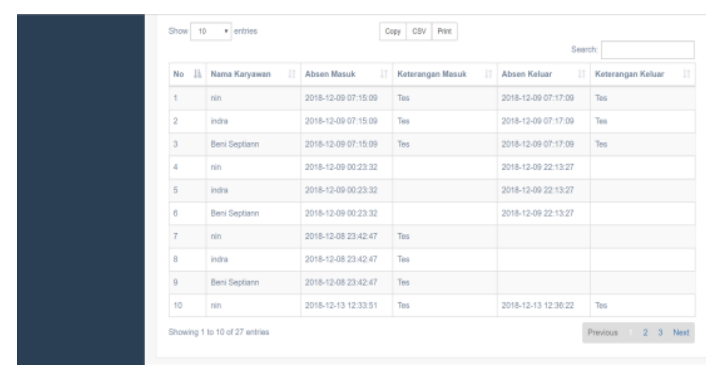

Gambar 18. Halaman Daftar Absensi Karyawan Pada menu ini dapat dilihat daftar absensi karyawan, daftar absensi bisa export ke pdf ataupun csv. Daftar absensi ini nantinya akan diintergrasikan pada penghitungan gaji karyawan.

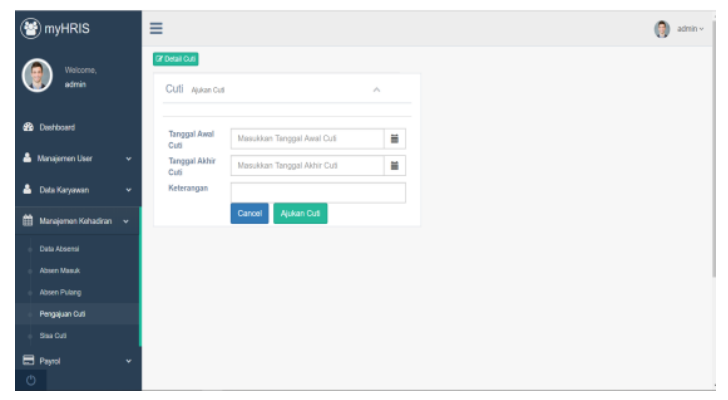

Gambar 19. Halaman Pengajuan Cuti Pada menu ini karyawan dapat melakukan pengajuan cuti dan akan dilakukan persetujuan oleh HRD atau manajer. 


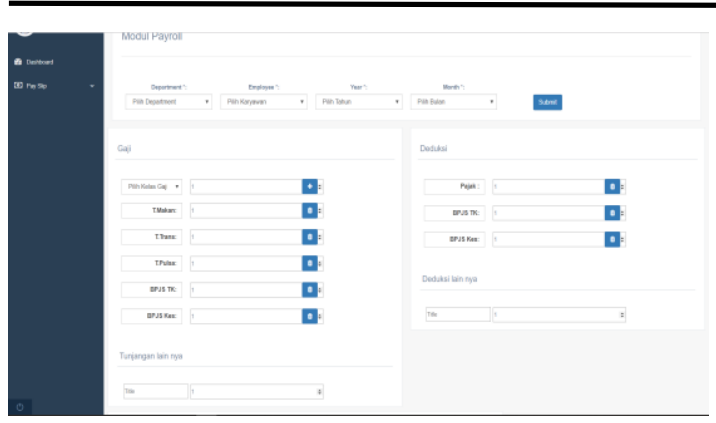

Gambar 20. Halaman Penghitungan Gaji

Pada menu penghitungan gaji karyawan dapat dilakukan penghitungan gaji karyawan yang terintegrasi dengan absensi karyawan dan potongan sesuai dengann level karyawan. Hasil slip gaji karyawan dapat di export dalam pdf.

\section{KESIMPULAN}

Kesimpulan dari penilitian ini dengan adanya aplikasi human capital manajemen pada proses pengelolaan lowongan pekerjaan dapat meningkatkan jumlah pelamar pekerjaan dan dapat meningkatkan filterisasi dengan profile matching sehingga mengurangi kesalahan dan mempercepat proses administrasi. Pada proses pencatatan absensi dan pengajuan cuti karyawan dan penghitungan gaji karyawan memberikan informasi yang akurat serta lebih efektif dan efisien. Dan pada pengenghitungan gaji karyawan memudahkan perusahaan karena terintegrasi dengan absensi karyawan serta meminimalisir kesalahan.

\section{DAFTAR PUSTAKA}

Alfiandi, F., Kertahadi, K., \& Nuzula, N. F. (2014). The Implementation of Payroll Accounting System as an Effort to Improve the System of Internal Control (a Study at Pdam Kota Malang). Jurnal Administrasi Bisnis S1 Universitas Brawijaya, 14(1), 1-10.

Ayu, W., \& Perdana, I. (2014). PERANCANGAN SISTEM INFOR-MASI REKRUTMEN DAN SELEK-SI KARYAWAN BERBASIS WEB DI PT. QWORDS COMPANY INTERNATIONAL. Jurnal Manajemen
Indonesia, 14(3), 247-258.

Dedi, D., Fuad, H., \& Setiawan, A. (2014). Perancangan Sistem Informasi Human Resources Pada PT . Indonesia Koito. Jurnal Sisfotek Global, 1(1), 9-11.

Ependi, U. (2018). Implementasi Model Scrum pada Sistem Informasi Seleksi Masuk Mahasiswa Politeknik Pariwisata Palembang. Jurnal Informatika : Jurnal pengembangan IT, 49-55.

Habibie, F. H. (2012). Pembangunan Sistem Informasi Penerimaan Calon Tenaga Kerja Secara Online Berbasis Web Pada Bursa Kerja Khusus Smk Ganesha Tama Boyolali. Jurnal Speed 13 FTI UNSA, 1-7.

Handriani, I., Sidik, S., Noor, A., Multazam, A., \& Wijaya, I. (2019). Aplikasi Perekrutan dan Penempatan Karyawan Baru Berbasis Web (Studi Kasus PT Bfi Finance Indonesia Tbk). Ensiklopedia of Journal, 1(2), 117125.

Jogiyanto, H. M. (2005). Sistem Teknologi Informasi.

Lestari, D. (2014). Perancangan Sistem Informasi Penggajian Karyawan pada PR. Tunas Mandiri Kabupaten Pacitan. Indonesian Journal of Network \& Security, 3(4), 22-26.

Meiastoko, D., Kertahardi, K., \& Susilo, H. (2013). Implementasi Sistem Informasi Sumber Daya Manusia dalam Kegiatan Rekuritmen Karyawan (Studi pada PT. Aneka Jasa Grhadika). Jurnal Administrasi Bisnis, 6(2), 1-8.

Rahman, S., Setiawan, A., \& Handriani, I. (2019). Sistem Pencatatan Dan Pendataan Manajemen Sumber Daya Manusia Dengan Model 
Scrum ( Studi Kasus : Pt Bintang Trans Khatulistiwa ). Journal Scientifics and Applied Informatics, 105-115.

Ranggadara, I., \& Suhendra, S. (2018). Zachman Framework Approach for Designing Recruitment System Modules in HRIS Application ( Case Study in PT . Karya Impian Teknologi Abadi . IJCSMC, 7(2), 73-79.

Rubin, K. S. (2012). Essential Scrum : A Practical Guide to the Most Popular Agile Process.

Setyabudhi, A. L. (2017). Perancangan Sistem Informasi Pengolahan Data
Absensi dan Pengambilan Surat Cuti Kerja Berbasis Web. Jurnal Responsive Teknik Informatika, 1(1), 11-22.

Shelly, G. B., \& Rosenblatt, H. J. (2012). Analysis and Design for Systems 9th ed. Course Technology Cengage Learning.

Wibawa, J., \& Julianto, F. (2016). Rancang Bangun Sistem Informasi Kepegawaian (Studi Kasus: PT Dekatama Centra). Jurnal Teknik Informatika dan Sistem Informasi, 2(2), 173-185. 